\title{
Pemanfaatan Limbah Plastik (Polyethylene Terephthalate) Sebagai Pengganti Agregat Halus Dalam Pembuatan Paving Block
}

\author{
Utilization of Plastic Waste (Polyethylene Terephthalate) as a Substitute for Fine Aggregate \\ in Paving Block Manufacturing
}

\author{
Andika Surya ${ }^{1 *}$, Dedi Arham Al Anzari ${ }^{1}$, Ana Juniarti ${ }^{1}$, Arman Setiawan ${ }^{1}$ \\ "Email: andikasurya230598@gmail.com \\ ${ }^{1}$ Program Studi Teknik Sipil Fakultas Teknik Universitas Bosowa \\ Diterima: 10 September 2021 / Disetujui: 21 Desember 2021
}

\begin{abstract}
ABSTRAK
Penelitian ini mempunyai kelebihan diantaranya mampu menjadi salah satu alternatif untuk mengurangi jumlah sampah plastik jenis PET sebagai salah satu bahan kontruksi yaitu paving block yang ramah lingkungan dan dapat digunakan sebagai pengerasan jalan, taman maupun pelataran parkir. Paving block adalah suatu komposisi bahan bangunan yang terbuat dari campuran semen portland atau bahan perekat hidrolis lainnya, air dan agregat dengan atau tanpa bahan tambahan lainnya yang tidak mengurangi mutu beton tersebut (SNI 03-0691-1996). Komposisi paving block yang akan dibuat pada karya ini terdiri dari semen portland,pasir,limbah plastik dan air sebagai campuran yang akan direncanakan pada perancangan pembuatan paving block. Masyarakat belum banyak mengetahui bahwasanya plastik juga bisa dijadikan salah satu bahan kontruksi dengan menjadi bahan tambahan. Paving block dengan plastik ini tidak bisa diragukan kekuatannya seperti paving block pada umumnya. Karena dari penelitian sebelumnya menunjukkan bahwa paving block dengan menggunakan serat yang terdapat pada plastik dapat meningkatkan kuat tekan pada paving. Hasil uji menunjukkan bahwa hasil paving block campuran 1: 3 dengan kuat tekan paving normal 18.07 Mpa dan paving block campuran 1:6 dengan kuat tekan paving normal 11.32 MPa maka dapat diperkirakan hasil narrative review yang sesuai penelitian kami adalah sebagai berikut, pada paving block komposisi 1:4, kuat tekan target yang terjadi direncanakan sebesar $15 \mathrm{Mpa}$ dan paving block kompisisi 1:5 kuat tekan target rencana direncanakan sebesar 13 Mpa dengan tingkat kepercayaan data $R=0.9798$ dari penggambungan data sebelumnya,Dengan penggunaan subtitusi plastic terhadap pasir, maka ditargetkan akan terjadi peningkatan kuat tekan sebesar 30\% dari paving block tanpa penggunaan plastic di komposisi subtitusi plastic sebesar 40\%.Berdasarkan SNI 03-0691-1996 tentang klarifikasi mutu paving block, komposisi paving dengan subtitusi plastic $1: 4$ dan $1: 5$ cocok untuk digunakan pada taman kota dan pedestrian untuk pejalan kaki.
\end{abstract}

Kata Kunci: Paving Block, Polyethylene Terephthalate, Agregat Halus, Kuat Tekan

\section{ABSTRACT}

Then, what if the plastic waste can be used. This research has advantages such as being able to be an alternative to reduce the amount of PET plastic waste as a construction material, namely paving blocks that are environmentally friendly and can be used as paving roads, parks and parking lots. Paving block is a building material composition made of a mixture of portland cement or other hydraulic adhesives, water and aggregates with or without other additives that do not reduce the quality of the concrete (SNI 03-0691-1996). The composition of the paving blocks that will be made in this work consists of portland cement, sand, plastic waste and water as a mixture that will be planned in the design of making paving blocks. People don't know much that plastic can also be used as a construction material by becoming an additional material. Paving blocks with plastic cannot be doubted as strong as paving blocks in general. This is because previous research shows that paving blocks using fibers found in plastic can increase the compressive strength of paving. The test results show that the results of a 1:3 mixed paving block with a normal compressive strength of $18.07 \mathrm{MPa}$ and a mixed paving 
block of 1:6 with a normal compressive strength of $11.32 \mathrm{MPa}$ can then be estimated that the results of a narrative review according to our research are as follows, on the paving block composition. 1: 4, the planned target compressive strength is $15 \mathrm{MPa}$ and the paving block composition 1:5 is the planned target compressive strength is $13 \mathrm{MPa}$ with a data confidence level of $R=0.9798$ from combining the previous data. With the use of plastic substitution for sand, it is targeted to there is an increase in compressive strength of $30 \%$ from paving blocks without the use of plastic in the composition of plastic substitution by $40 \%$. city parks and pedestrians for pedestrians.

Keywords: Paving Block, Polyethylene Terephthalate, Fine Aggregate, Compressive Strength

\section{A. PENDAHULUAN}

Polusi plastik adalah akumulasi dari produk plastik yang ada di lingkungan yang berdampak buruk terhadap satwa liar, habitat satwa liar, dan manusia.Plastik yang berperan sebagai polutan dikategorikan ke dalam mikro, meso, atau puing- puing makro, berdasarkan ukurannya.Plastik berharga murah, tahan lama, dan hasilnya tingkat produksi plastik oleh manusia menjadi tinggi. Namun, umumnya struktur kimia dari plastik membuat mereka tahan terhadap banyak proses alami degradasi dan akibatnya mereka lambat juga untuk didegradasi.Bersama-sama, kedua faktor inilah yang menyebabkan tingginya tingkat pencemaran plastik di lingkungan.

Dalam penelitian ini kami menggunakan limbah plastik PET sebagai subtitusi agregat halus dalam campuran paving block agar dapat mensubtitusi limbah plastik yang tadinya tidak bermanfaat memiliki nilai ekonomis. Berdasarkan uraian yang telah dipaparkan maka dapat dirumuskan masalah sebagai berikut: 1). Bagaimana pemanfaatan plastik sebagai subtitusi agregat halus terhadap kuat tekan paving block? 2). Bagaimana komposisi optimum penggunaan limbah plastik sebagai subtitusi agregat halus terhadap kuat tekan paving block?. Adapun tujuan dari penelitian ini antara lain : 1) Untuk Menganalisa pengaruh penggunaan limbah plastik sebagai subtitusi agregat halus terhadap kuat tekan paving block, 2) Untuk Mengetahui komposisi optimum penggunaan limbah plastik pada campuran paving block, 3) Untuk Memahami pengaruh penggunaan limbah plastic sebagai subtitusi agregat halus pada campuran paving block. Adapun manfaat dari penelitian ini adalah : 1) Mampu Menganalisa pengaruh penggunaan limbah plastik sebagai subtitusi agregat halus pada campuran paving block, 20 Mampu Mengetahui komposisi optimum penggunaan limbah plastik pada campuran paving block, 3) Mampu Memahami pengaruh penggunaan limbah plastik 
sebagai subtitusi agregat halus pada campuran paving block.

\section{B. METODE PENELITIAN}

Waktu pelaksanaan penelitian ini dimulai dari 13 Agustus 2020 sampai dengan 30 september 2020 yang dilakukan dengan system daring.

\section{HASIL DAN PEMBAHASAN}

\section{Analisis Potensi Pakan}

Berdasarkan review jurnal dan skripsi online, kami merangkum beberapa jurnal yang hampir terdapat persamaan dengan penelitian yang kami lakukan, yaitu sebagai berikut:

1. Qurrota Ayyuni Luthfianti (2019), Pemanfaatan Sampah Plastik Jenis Polyethylene Terephthalate (PET)

Sebagai Substitusi Agregat Halus Pada Paving Block


Dari hasil pengujian yang dilakukan, nilai rata-rata kuat tekan menunjukkan peningkatan disetiap komposisinya dengan mengsubtitusi plastic terhadap pasir hingga komposisi penambahan plastic $0.5 \%$ sebesar $14.55 \mathrm{MPa}$ dan penurunan nilai kuat tekan terjadi pada komposisi penambahan plastic $0.6 \%$ sebesar $11.82 \mathrm{MPa}$ dengan tingkat kepercayaan data sebesar $\mathrm{R}=0.1714$.

2. Gardika Ardhya Kusuma (2019), Pemanfaatan Sampah Plastik Jenis PP (Poly Propylene) sebagai Substitusi Agregat pada Bata Beton (Paving Block)

Dari hasil pengujian yang dilakukan, PENGUJIAN KUAT TEKAN PAVING BLOCK $1: 6$

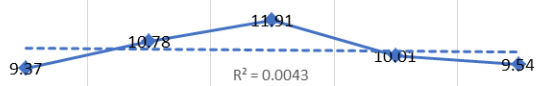

nilai rata-rata kuat tekan menunjukkan peningkatan disetiap komposisinya dengan mengsubtitusi plastic terhadap pasir hingga komposisi penambahan plastic $0.4 \%$ sebesar $11.91 \mathrm{MPa}$ dan penurunan nilai kuat tekan terjadi pada komposisi penambahan plastic hingga $0.6 \%$ sebesar 9.54 MPa dengan tingkat kepercayaan data sebesar $\mathrm{R}=0.0043$.

3. Khonsa, Devina Hanan Elhusna, Elhusna Ade, Sri Wahyuni (2019), Pengaruh pemanfaatan limbah plastik PENGUJIAN KUAT TEKAN PAVING BLOCK $1: 3$ 30.00 25.00 20.00

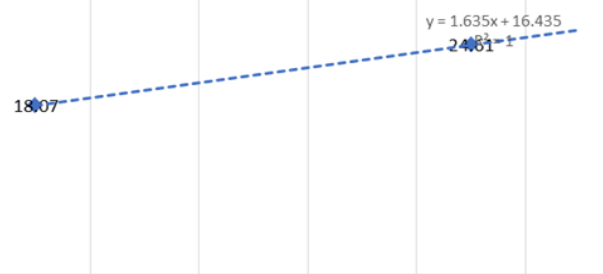


Dari hasil pengujian yang dilakukan, nilai rata-rata kuat tekan terjadi pada komposisi subtitusi plastic terhadap pasir sebesar $40 \%$ terhadap pasir sebesar 24.61 MPA. Berdasarkan hasil penelitian sebelumnya dapat disimpulkan bahwa terjadi peningkatan kuat tekan dari paving block normal ke paving block variasi campuran plastic sebesar $27 \%-36 \%$.

Hasil Kajian data sebelumnya terhadap penelitian peneliti:

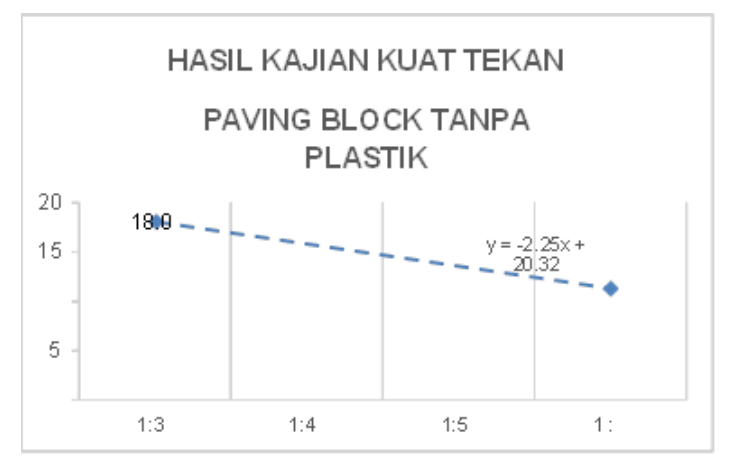

Dengan merujuk hasil paving block campuran 1: 3 dengan kuat tekan paving normal 18.07 Mpa dan paving block campuran 1:6 dengan kuat tekan paving normal 11.32 MPa maka dapat diperkirakan hasil narrative review yang sesuai penelitian kami
Untuk paving block komposisi 1: 4, kuat tekan target yang terjadi direncanakan sebesar 15.82 Mpa dan paving block kompisisi 1:5 kuat tekan target rencana direncanakan sebesar 13.57 Mpa dengan tingkat kepercayaan data $\mathrm{R}=1$ dari penggabungan data sebelumnya

1. Dengan penggunaan subtitusi plastic terhadap pasir, maka ditargetkan akan terjadi peningkatan kuat tekan sebesar $30 \%$ dari paving block tanpa penggunaan plastic di komposisi subtitusi plastic sebesar $40 \%$, sehingga PB 1:4 sebesar 22,148 Mpa sedangkan pada PB 1:5 sebesar 18,998 Mpa.

2. Berdasarkan SNI 03-0691-1996 tentang klarifikasi mutu paving block, komposisi paving dengan subtitusi plastic $1: 4$ dan $1: 5$ cocok untuk digunakan pada taman kota dan pedestrian untuk pejalan kaki.

\section{KESIMPULAN DAN SARAN}

Hasil uji menunjukkan bahwa hasil paving block campuran 1: 3 dengan kuat tekan paving normal 18.07 Mpa dan paving block campuran 1:6 dengan kuat tekan paving normal $11.32 \mathrm{MPa}$ maka dapat diperkirakan hasil narrative review yang sesuai penelitian kami adalah sebagai berikut, pada paving block komposisi 1: 4 , kuat tekan target yang terjadi direncanakan sebesar 15 Mpa dan paving block 
kompisisi 1:5 kuat tekan target rencana direncanakan sebesar 13 Mpa dengan tingkat kepercayaan data $\mathrm{R}=0.9798$ dari penggambungan data sebelumnya,Dengan penggunaan subtitusi plastic terhadap pasir, maka ditargetkan akan terjadi peningkatan kuat tekan sebesar 30\% dari paving block tanpa penggunaan plastic di komposisi subtitusi plastic sebesar 40\%.Berdasarkan SNI 03-0691-1996 tentang klarifikasi mutu paving block, komposisi paving dengan subtitusi plastic $1: 4$ dan $1: 5$ cocok untuk digunakan pada taman kota dan pedestrian untuk pejalan kaki.

\section{DAFTAR PUSTAKA}

Ariyadi (2019), Uji Pembuatan Paving Block Menggunakan Campuran Limbah Plastik Jenis Pet (Poly Ethylene Terephthalate) Pada Skala Laboratorium.

Budi Indrawijaya, Ahmad wibisana, Agustina Dyah Setyowati, Didik Iswadi, Deno Prianto Naufal, Desi Pratiwi(2019), Pemanfaatan Limbah Plastik Ldpe Sebagai Pengganti Agregat untuk Pembuatan Paving Blok Beton.

Burhanuddin, Basuki,MRS Darmanijati(2018), Pemanfaatan Limbah Plastik Bekas Untuk Bahan Utama Pembuatan Paving Block.

Dedi Enda, Marhadi Sastra, Lizar, Zulkarnain,Boby Rahman (2019), Penggunaan Plastik Tipe Pet Sebagai PenggantiSemen Pada Pembuatan Paving Block.

Fauna Adibroto (2014), Pengaruh Penambahan Berbagai Jenis Serat Pada Kuat Tekan Paving Block.
Gardika Ardhya Kusuma (2019), Pemanfaatan Sampah Plastik Jenis PP (Poly Propylene) sebagai Substitusi Agregat pada Bata Beton (Paving Block).

Husaini, Mahdi (2015), Penggunaan Limbah Botol Plastik Sebagai Agregat Pada Campuran Beton Dengan Penambahan Silika Fume.

Isnawati (2015), Pengaruh Penambahan Agregat Limbah Plastik Terhadap Kuat Tekan Beton Semen.

Indah Handayasari, Gita Puspa Artiani, Desi Putri (2018), Bahan Konstruksi Ramah Lingkungan Dengan Pemanfaatan Limbah Botol Plastik Kemasan Air Mineral Dan Limbah Kulit Kerang Hijau Sebagai Campuran Paving Block.

Khonsa, Devina Hanan Elhusna, Elhusna Ade, Sri Wahyuni (2019), Pengaruh pemanfaatan limbah plastik pet (poly ethylene terephthalate) sebagai pengganti agregat halus terhadap kuat tekan mortar (kajian terhadap adukan mortar $1 \mathrm{pc}: 3 \mathrm{ps})$.

Lalu Syamsul Hadi (2018), Pemanfaatan Limbah Plastik Polyethylene Terepthalate (Pet) Untuk Bahan Tambahan Pembuatan Paving Block.

Qurrota Ayyuni Luthfianti (2019), Pemanfaatan Sampah Plastik Jenis Polyethylene Terephthalate (PET) Sebagai Substitusi Agregat Halus Pada Paving Block.

Supratikno, Ratnanik (2019), Pemanfaatan Limbah Plastik sebagai Pengganti Agregat Kasar pada Campuran Beton.

Taufiq Ilham Maulana (2017), Studi Kuat Tekan Material Pasir Berbahan Campur Sampah Kaca dan Plastik Rumah Tangga.

Yessi Rismayasari (2012), Pembuatan Beton Dengan Campuran Limbah Plastik Dan Karakterisasinya.

Yusuf Amran (2015), Pemanfaatan Limbah Plastik Untuk Bahan 
Tambahan Pembuatan Paving Block Sebagai Alternatif Perkerasan Pada Lahan Parkir Di Universitas Muhammadiyah Metro. 